\title{
Carbon dioxide regulation of nitrogen and phosphorus in four species of marine phytoplankton
}

\author{
John R. Reinfelder* \\ Department of Environmental Sciences, Rutgers University, 14 College Farm Road, New Brunswick, New Jersey 08901-8551, USA
}

\begin{abstract}
The concentration of carbon dioxide in seawater may affect phytoplankton physiology and ecology and their role in marine biogeochemical cycles. In order to assess the effects of $\mathrm{CO}_{2}$ on the elemental composition of marine phytoplankon, carbon, nitrogen, and phosphorus quotas were measured in 4 species of marine phytoplankton acclimated to 150 to $1500 \mathrm{ppm} \mathrm{CO}_{2}$ ( 5 to $50 \mu \mathrm{M}$ ) in semi-continuous cultures. Nitrogen quotas declined steeply with increasing $\mathrm{CO}_{2}$ in the centric diatoms Thalassiosira pseudonana and T. weissflogii acclimated to 150 to $380 \mathrm{ppm}$ (5 to $13 \mu \mathrm{M})$, but more slowly as the $\mathrm{CO}_{2}$ increased from 380 to $1500 \mathrm{ppm}$ (13 to $\left.50 \mu \mathrm{M}\right)$. Nitrogen demand varied little with $\mathrm{CO}_{2}$ in the pennate diatom Phaeodactylum tricornutum, but was positively correlated with $\mathrm{CO}_{2}$ over the range of 150 to $770 \mathrm{ppm}$ in the prymnesiophyte Isochrysis galbana. Based on the nitrogen- $\mathrm{CO}_{2}$ trends in centric diatoms, relief from carbon-nitrogen colimitation could lead to 2-fold larger cells as $\mathrm{CO}_{2}$ increases from 150 to 380 ppm, but only $15 \%$ larger cells from 380 to $770 \mathrm{ppm} \mathrm{CO}$. Phosphorus quotas in the 3 diatoms decreased as $\mathrm{CO}_{2}$ increased from 150 to $380 \mathrm{ppm}$. As previously observed in these and other species, C:N, C:P, and $\mathrm{N}$ :P ratios increased with increasing $\mathrm{CO}_{2}$, but the present results show that much of this variation was due to differences in nitrogen and phosphorus rather than carbon quotas. Marine phytoplankton could provide a negative feedback against increasing $\mathrm{CO}_{2}$ over the $\mathrm{pCO}_{2}$ range of 150 to 380 ppm by supporting larger cells or higher biomass, but would support a smaller carbon sink as atmospheric $\mathrm{CO}_{2}$ rises above 380 ppm.
\end{abstract}

KEY WORDS: Nitrogen $\cdot$ Phosphorus $\cdot$ Carbon dioxide $\cdot$ Phytoplankton

\section{INTRODUCTION}

The elemental composition of marine phytoplankton varies among species (Arrigo et al. 2002, Geider \& La Roche 2002, Ho et al. 2003, Quigg et al. 2003) and within species depending on the extent of nutrient (Goldman et al. 1979, Price 2005, Moore et al. 2007, Varela et al. 2011) or light (Leonardos \& Geider 2004, Finkel et al. 2006) limitation of growth. Since marine phytoplankton use various strategies to concentrate inorganic carbon for photosynthesis (Giordano et al. 2005, Raven et al. 2011, Reinfelder 2011), which carry metabolic costs (Raven \& Johnston 1991, Raven et al. 2012), element ratios in phytoplankton may also depend on inorganic carbon supply, but this is only beginning to be examined (Hutchins et al. 2009, Montechiaro \& Giordano 2010).
Inorganic carbon concentrating mechanisms (CCMs) in marine phytoplankton are characterized by increased activities of the enzyme carbonic anhydrase (Morel et al. 1994, Rost et al. 2003, Dason et al. 2004), an ability to use $\mathrm{HCO}_{3}{ }^{-}$for photosynthesis (Tortell et al. 1997, 2008a, Cassar et al. 2004, Hopkinson et al. 2011), and, in at least some $\mathrm{C}_{3}-\mathrm{C}_{4}$ intermediate species of marine diatoms, up-regulation of a single-cell, $\mathrm{C}_{4}$ carbon pump (Reinfelder et al. 2000, 2004, Roberts et al. 2007, McGinn \& Morel 2008). Physiological changes associated with CCMs impose resource and energy costs on cells at ambient or lower concentrations of $\mathrm{CO}_{2}$ (Raven \& Johnston 1991, Beardall \& Giordano 2002, Raven et al. 2012), and as a result, the concentration of $\mathrm{CO}_{2}$ in seawater has the potential to regulate phytoplankton physiology, ecology, and biogeochemistry (Rost et al. 2008, Raven et 
stant (no longer increasing) growth rates. With this method of control, the concentrations of aqueous carbon dioxide $\left(\mathrm{CO}_{2 \mathrm{aq}}\right)$, dissolved inorganic carbon (DIC), and pH vary with the partial pressure of $\mathrm{CO}_{2}$ $\left(\mathrm{pCO}_{2}\right)$ at constant alkalinity as would occur in surface ocean seawater under conditions of variable atmospheric $\mathrm{CO}_{2}$ (Rost et al. 2008). This approach contrasts with methods in which $\mathrm{pH}, \mathrm{DIC}$, and carbonate or non-carbonate alkalinity are varied (Burkhardt et al. 1999, Clark 2001) and dampens diurnal swings in $\mathrm{CO}_{2}$ and $\mathrm{pH}$ as occurs in non-bubbled cultures (Shi et al. 2009). Maintenance of nominal concentrations of $\mathrm{CO}_{2}$ during phytoplankton growth was monitored by periodically measuring $\mathrm{pH}_{\mathrm{NBS}}$ (National Bureau of Standards calibration scale) of bubbled cultures. Based on measurements of cultures at the time of harvest, $\mathrm{CO}_{2}$ concentrations were at most $40 \mathrm{ppm}(1.3 \mu \mathrm{M})$ lower than nominal values for 150, 280, and $380 \mathrm{ppm}$ cultures, $100 \mathrm{ppm}$ $(3.4 \mu \mathrm{M})$ lower for $770 \mathrm{ppm}$ cultures, and $200 \mathrm{ppm}$ $(7 \mu \mathrm{M})$ lower for $1500 \mathrm{ppm}$ cultures. The alkalinity of the synthetic seawater media was calculated based on the balance of acids and bases in the recipe. Concentrations of $\mathrm{CO}_{2 \mathrm{aq}}$ were calculated with the CDIAC $\mathrm{CO}_{2}$ system software (Lewis \& Wallace 1998) using alkalinity and $\mathrm{CO}_{2}$ partial pressures as input and the dissociation constants of Roy et al. (1993).

Biological replicates were grown for each species acclimated to $380 \mathrm{ppm} \mathrm{CO}_{2}$ including triplicate cultures for 3 of 4 species and duplicate cultures for Thalassiosira weissflogii. At other $\mathrm{CO}_{2}$ concentrations, duplicate or single cultures were grown. Based on the variation among biological replicates, between-culture variability was estimated to be between 2 and $6 \%$ for carbon, 4 and $13 \%$ for nitrogen, and 6 and $19 \%$ for phosphorus. Cultures were harvested after 80 to $90 \%$ of nitrate was consumed to minimize intracellular nitrogen storage. Cell samples were collected in triplicate (analytical replicates) for organic carbon and nitrogen analysis on pre-combusted glass fiber filters (GF/F) and for organic phosphorus on polycarbonate filters, and subsequently rinsed with nutrientfree synthetic seawater. Additional samples were collected for cell enumeration and sizing by Coulter Counter analysis and microscopic examination. Particulate organic carbon and nitrogen were analyzed using a Carlo-Erba element analyzer after acidification to remove inorganic carbon. Phosphorus was analyzed by the molybdate blue method after persulfate digestion (Parsons et al. 1984, Clesceri et al. 1998).

Nitrogen quotas in the 2 centric diatoms were used to estimate the maximum diatom cell volume that could support nitrate-diffusion-limited growth at each experimental $\mathrm{CO}_{2}$ concentration. Equivalent spherical radii $(R)$ of diatom cells capable of maintaining a specified nutrient quota under diffusion-limited nitrate supply were estimated by equating the cell volumespecific nitrate uptake rate and the diffusion-limited flux of nitrate through the cell's boundary layer:

$$
\begin{gathered}
\mu Q_{\mathrm{v}}=4 \pi R D\left(\mathrm{~N}_{\mathrm{sw}}-\mathrm{N}_{\mathrm{R}}\right) / 4 \pi R^{3} / 3 \\
\mu Q_{\mathrm{v}}=3 D\left(\mathrm{~N}_{\mathrm{sw}}-\mathrm{N}_{\mathrm{R}}\right) / R^{2}
\end{gathered}
$$

where $\mu$ is the specific growth rate $\left(\mathrm{d}^{-1}\right), Q_{\mathrm{v}}$ is the volume-specific nitrogen quota $\left(\mathrm{mol} \mathrm{l}^{-1}\right), D$ is the diffusion coefficient of nitrate in seawater $\left(\mathrm{m}^{2} \mathrm{~s}^{-1}\right), \mathrm{N}_{\mathrm{sw}}$ and $N_{R}$ are the concentrations of nitrate $\left(\mathrm{mol} \mathrm{m}^{-3}\right)$ in surface ocean seawater and at the surface of the cell, respectively. The diffusion coefficient for nitrate in water with the same ionic strength as seawater is $1.3 \times 10^{-9} \mathrm{~m}^{2} \mathrm{~s}^{-1}$ (Yeh \& Wills 1970). For the criterion of growth at $2 / 3$ of the diffusion-limited nitrate flux, an arbitrary constraint that represents the nitrate concentration gradient between the cell surface and bulk medium likely to occur under nitrogen limiting conditions, $\mathrm{N}_{\mathrm{R}}=1 / 3 \mathrm{~N}_{\mathrm{sw}}$. Solving for $R$ :

$$
R=\left(2 D \mathrm{~N}_{\mathrm{sw}} / \mu Q_{V}\right)^{1 / 2}
$$

Diffusion-limited diatom cell radii were calculated for a growth rate of $1 \mathrm{~d}^{-1}$ using the average volumespecific nitrogen quotas of Thalassiosira pseudonana and $T$. weissflogii measured at each concentration of $\mathrm{CO}_{2}$ and a surface seawater nitrate concentration of $0.5 \mu \mathrm{M}$.

Relative contributions of changes in nitrogen and phosphorus quotas to changes in $\mathrm{C}: \mathrm{N}, \mathrm{C}: \mathrm{P}$, and $\mathrm{N}: \mathrm{P}$ ratios were estimated for each $\mathrm{CO}_{2}$ concentration interval. For example, the relative contribution of the change in nitrogen quota to the C:N ratio $\left(\% \mathrm{~N}_{\mathrm{C}: \mathrm{N}}\right)$ was estimated as:

$$
\% \mathrm{~N}_{\mathrm{C}: \mathrm{N}}=\Delta \mathrm{N} / \mathrm{N}_{\mathrm{ave}} /\left(\Delta \mathrm{N} / \mathrm{N}_{\mathrm{ave}}+\Delta \mathrm{C} / \mathrm{C}_{\mathrm{ave}}\right)
$$

where $\Delta \mathrm{N}$ and $\Delta \mathrm{C}$ are the differences in cell quotas in cells acclimated to 2 different concentrations of $\mathrm{CO}_{2}$ and $\mathrm{N}_{\mathrm{ave}}$ and $\mathrm{C}_{\mathrm{ave}}$ are the average cell quotas for those concentrations of $\mathrm{CO}_{2}$.

Trends in element quotas and ratios in cells acclimated to different concentrations of $\mathrm{CO}_{2}$ were evaluated by either linear regression analysis or by comparing pooled values using 2-tailed $t$-tests for equal or unequal variance as determined by the $F$-test of variance. Correlations and differences were considered significant for $p<0.1$. Since phosphorus quotas were measured in different physical samples than carbon and nitrogen quotas, differences in C:P and $\mathrm{N}$ :P ratios were compared using random pairs of carbon or nitrogen and phosphorus quotas. 
Table 3. Isochrysis galbana, Phaeodactylum tricornutum, Thalassiosira pseudonana, T. weissflogii. Cell volume-specific carbon, nitrogen, and phosphorus quotas $\left(\mathrm{mol} \mathrm{l}^{-1}\right)$ in 4 species of marine phytoplankton acclimated to various concentrations of aqueous $\mathrm{CO}_{2}\left(\mathrm{CO}_{2 \mathrm{aq}}\right)$ and corresponding partial pressures $\left(\mathrm{pCO}_{2}\right)$. Values are means $( \pm 1 \mathrm{SD})$. Within each column, groups of values marked with an asterisk or cross were correlated with the concentration of $\mathrm{CO}_{2}(\mathrm{p}<0.1)$. nc: not cultured; nd: not determined

\begin{tabular}{|c|c|c|c|c|c|c|c|c|c|c|c|c|c|}
\hline \multirow{2}{*}{$\begin{array}{l}{\left[\mathrm{CO}_{2 \mathrm{aq}}\right]} \\
(\mu \mathrm{M})\end{array}$} & \multirow{2}{*}{$\begin{array}{l}\mathrm{pCO}_{2} \\
(\mathrm{ppm})\end{array}$} & \multicolumn{3}{|c|}{ I. galbana } & \multicolumn{3}{|c|}{ P. tricornutum } & \multicolumn{3}{|c|}{ T. pseudonana } & \multicolumn{3}{|c|}{ T. weissflogii } \\
\hline & & $\mathrm{C}$ & $\mathrm{N}$ & $\mathrm{P}$ & $\mathrm{C}$ & $\mathrm{N}$ & $\mathrm{P}$ & $\mathrm{C}$ & $\mathrm{N}$ & $\mathrm{P}$ & $\mathrm{C}$ & $\mathrm{N}$ & $\mathrm{P}$ \\
\hline 5.2 & 150 & $\begin{array}{l}16.9 \\
(0.6)\end{array}$ & $\begin{array}{l}1.85^{*} \\
(0.06)\end{array}$ & $\begin{array}{c}0.131 \\
(0.015)\end{array}$ & $\begin{array}{l}31.8 \\
(0.6)\end{array}$ & $\begin{array}{c}3.84 \\
(0.04)\end{array}$ & $\begin{array}{l}0.285^{*} \\
(0.027)\end{array}$ & $\begin{array}{l}14.7 \\
(0.4)\end{array}$ & $\begin{array}{l}1.46^{*} \\
(0.08)\end{array}$ & $\begin{array}{l}0.278^{*} \\
(0.041)\end{array}$ & $\begin{array}{l}14.8 \\
(0.3)\end{array}$ & $\begin{array}{l}1.60^{*} \\
(0.09)\end{array}$ & $\begin{array}{l}0.134^{*} \\
(0.013)\end{array}$ \\
\hline 9.7 & 280 & $\begin{array}{l}18.1 \\
(1.6)\end{array}$ & $\begin{array}{l}1.99^{*} \\
(0.15)\end{array}$ & nd & $\mathrm{nc}$ & $\mathrm{nc}$ & $\mathrm{nc}$ & $\begin{array}{c}19.0^{*} \\
(0.1)\end{array}$ & $\begin{array}{l}1.24^{*} \\
(0.05)\end{array}$ & $\begin{array}{l}0.134^{*} \\
(0.009)\end{array}$ & $\begin{array}{l}11.9 \\
(0.3)\end{array}$ & $\begin{array}{l}1.16^{*} \\
(0.12)\end{array}$ & $\begin{array}{l}0.113^{*} \\
(0.002)\end{array}$ \\
\hline 13 & 380 & $\begin{array}{c}16.1^{*} \\
(0.3)\end{array}$ & $\begin{array}{l}2.20^{*} \\
(0.29)\end{array}$ & $\begin{array}{c}0.085 \\
(0.016)\end{array}$ & $\begin{array}{l}27.6 \\
(1.0)\end{array}$ & $\begin{array}{l}3.59 \\
(0.2)\end{array}$ & $\begin{array}{l}0.180^{*} \\
(0.004)\end{array}$ & $\begin{array}{c}18.7^{*} \\
(0.3)\end{array}$ & $\begin{array}{c}0.99 * \mp \\
(0.04)\end{array}$ & $\begin{array}{l}0.106^{*} \\
(0.010)\end{array}$ & $\begin{array}{l}10.1 \\
(0.6)\end{array}$ & $\begin{array}{l}1.00^{*} \\
(0.09)\end{array}$ & $\begin{array}{l}0.061^{*} \\
(0.004)\end{array}$ \\
\hline 27 & 770 & $\begin{array}{c}28.1^{*} \\
(0.3)\end{array}$ & $\begin{array}{l}2.88^{*} \\
(0.05)\end{array}$ & nd & $\begin{array}{l}26.6 \\
(0.1)\end{array}$ & $\begin{array}{l}3.51 \\
(0.2)\end{array}$ & $\begin{array}{c}0.182 \\
(0.018)\end{array}$ & $\begin{array}{c}17.1^{*} \\
(0.6)\end{array}$ & $\begin{array}{l}0.92 \mp \\
(0.03)\end{array}$ & $\begin{array}{c}0.098 \\
(0.003)\end{array}$ & $\begin{array}{l}14.7 \\
(0.7)\end{array}$ & $\begin{array}{c}0.89 \\
(0.04)\end{array}$ & $\begin{array}{c}0.053 \\
(0.004)\end{array}$ \\
\hline 52 & 1500 & $\begin{array}{c}32.5^{*} \\
(0.7)\end{array}$ & $\begin{array}{c}2.46 \\
(0.05)\end{array}$ & $\begin{array}{c}0.067 \\
(0.013)\end{array}$ & $\mathrm{nc}$ & $\mathrm{nc}$ & $\mathrm{nc}$ & $\begin{array}{l}13.2^{*} \\
(0.5)\end{array}$ & $\begin{array}{l}0.88 \mp \\
(0.14)\end{array}$ & $\begin{array}{c}0.083 \\
(0.011)\end{array}$ & $\begin{array}{l}13.5 \\
(2.0)\end{array}$ & $\begin{array}{c}0.91 \\
(0.12)\end{array}$ & $\begin{array}{c}0.061 \\
(0.011)\end{array}$ \\
\hline
\end{tabular}

\section{RESULTS}

Growth rates of the 4 phytoplankton species did not vary with the concentration of $\mathrm{CO}_{2}$ to which each was acclimated in these light- and nutrient-replete cultures (Morel et al. 1994, Tortell et al. 1997, Burkhardt et al. 1999) and averaged $0.72 \pm 0.1 \mathrm{~d}^{-1}$ for Isochrysis galbana, $1.3 \pm 0.04 \mathrm{~d}^{-1}$ for Phaeodactylum tricornutum, $1.6 \pm 0.2 \mathrm{~d}^{-1}$ for Thalassiosira pseudonana, and $0.90 \pm 0.06 \mathrm{~d}^{-1}$ for T. weissflogii. However, element quotas in the 4 species varied with respect to the concentration of $\mathrm{CO}_{2}$, and patterns of variation differed among species (Table 3). For example, carbon quotas decreased as the acclimation concentration of $\mathrm{CO}_{2}$ increased from 10 to $50 \mu \mathrm{M}$ in T. pseudonana $\left(\mathrm{R}^{2}=0.989, \mathrm{p}<0.01\right)$, but increased in $T$. weissflogii as $\mathrm{CO}_{2}$ increased from low $(10$ and $13 \mu \mathrm{M})$ to high $(27$ and $50 \mu \mathrm{M})$ values $(\mathrm{p}<0.01, t$-test $)$ and in I. galbana as $\mathrm{CO}_{2}$ increased from 13 to $50 \mu \mathrm{M}\left(\mathrm{R}^{2}=\right.$ $0.875, \mathrm{p}<0.05)$. Carbon quotas did not vary significantly with increasing $\mathrm{CO}_{2}\left(\mathrm{R}^{2}=\right.$ 0.573, $\mathrm{p}=0.14$ ) in P. tricornutum.

Nitrogen and phosphorus quotas also varied with acclimation $\mathrm{CO}_{2}$ (Table 3). For the centric diatoms Thalassiosira pseudonana and $T$. weissflogii, nitrogen quotas declined steeply with increasing $\mathrm{CO}_{2}$ from 5 to $13 \mu \mathrm{M}$, but more slowly or not at all in cells acclimated to 13 to $50 \mu \mathrm{M} \mathrm{CO}_{2}$. Thus as the concentration of $\mathrm{CO}_{2}$ increased from 5 to $13 \mu \mathrm{M}$, nitrogen quotas in $T$. pseudonana and $T$. weissflogii decreased by $61\left(\mathrm{R}^{2}=\right.$ 0.973, $\mathrm{p}<0.01)$ and $76\left(\mathrm{R}^{2}=0.938, \mathrm{p}<0.05\right)$ mmol $l^{-1}$ cell volume per $\mu \mathrm{M} \mathrm{CO}_{2}$, respec- tively. However, from 13 to $50 \mu \mathrm{M} \mathrm{CO}_{2}$, nitrogen quotas declined by only $3 \mathrm{mmol} \mathrm{l}^{-1}$ cell volume per $\mu \mathrm{M}$ $\mathrm{CO}_{2}$ in T. pseudonana $\left(\mathrm{R}^{2}=0.752, \mathrm{p}=0.06\right)$ and showed no significant decline in $T$. weissflogii $\left(\mathrm{R}^{2}=\right.$ $0.298, \mathrm{p}>0.1$ ). Nitrogen quotas in the pennate diatom Phaeodactylum tricornutum did not vary significantly with $\mathrm{CO}_{2}\left(\mathrm{R}^{2}=0.425, \mathrm{p}=0.23\right)$. Unlike nitrogen quotas in the centric diatoms, cellular nitrogen in Isochrysis galbana increased as $\mathrm{CO}_{2}$ increased from 5 to $27 \mu \mathrm{M}$. I. galbana cells acclimated to $27 \mu \mathrm{M}$ $\mathrm{CO}_{2}$ had a $45 \%$ higher nitrogen quota than cells acclimated to $10 \mu \mathrm{M}$, and nitrogen quotas were positively correlated with $\mathrm{CO}_{2}$ over the range of 5 to $27 \mu \mathrm{MCO}_{2}\left(\mathrm{R}^{2}=0.785, \mathrm{p}<0.05\right)$.

Higher nitrogen quotas at low $\mathrm{CO}_{2}$ increased the nitrogen costs of photosynthesis (mol $\mathrm{N}$ required to support the fixation of $1 \mathrm{~mol} \mathrm{C} \mathrm{d}^{-1}$ ) in Thalassiosira weissflogii and $T$. pseudonana as $\mathrm{CO}_{2}$ decreased from 27 to $5 \mu \mathrm{M}$ (Table 4). The nitrogen costs of pho-

Table 4. Isochrysis galbana, Phaeodactylum tricornutum, Thalassiosira pseudonana, $T$. weissflogii. Nitrogen cost of photosynthesis in 4 species of marine phytoplankton acclimated to various concentrations of aqueous $\mathrm{CO}_{2}\left(\mathrm{CO}_{2 \mathrm{aq}}\right)$ and corresponding partial pressures $\left(\mathrm{pCO}_{2}\right)$ in parts per million (ppm). Values are means ( $\pm 1 \mathrm{SD}$ ) in units of $\mathrm{mmol} \mathrm{N} \mathrm{mol}^{-1} \mathrm{C}$ fixed $\mathrm{d}^{-1}$ (i.e. $\mathrm{mmol} \mathrm{mol}^{-1} \mathrm{~d}^{-1}$ ). nc: not cultured

\begin{tabular}{|lccccc|}
\hline $\begin{array}{l}{\left[\mathrm{CO}_{2 \mathrm{aq}}\right]} \\
(\mu \mathrm{M})\end{array}$ & $\begin{array}{c}\mathrm{pCO}_{2} \\
(\mathrm{ppm})\end{array}$ & $\begin{array}{c}I . \\
\text { galbana }\end{array}$ & $\begin{array}{c}\text { P. } \\
\text { tricornutum }\end{array}$ & $\begin{array}{c}T . \\
\text { pseudonana }\end{array}$ & $\begin{array}{c}T . \\
\text { weissflogii }\end{array}$ \\
\hline 5.2 & 150 & $152(22)$ & $93(4)$ & $62(9)$ & $120(11)$ \\
9.7 & 280 & $153(27)$ & $\mathrm{nc}$ & $41(5)$ & $108(13)$ \\
13 & 380 & $187(36)$ & $100(7)$ & $33(4)$ & $108(14)$ \\
27 & 770 & $142(20)$ & $102(6)$ & $34(5)$ & $67(6)$ \\
52 & 1500 & $105(15)$ & $\mathrm{nc}$ & $41(8)$ & $70(13)$ \\
\hline
\end{tabular}



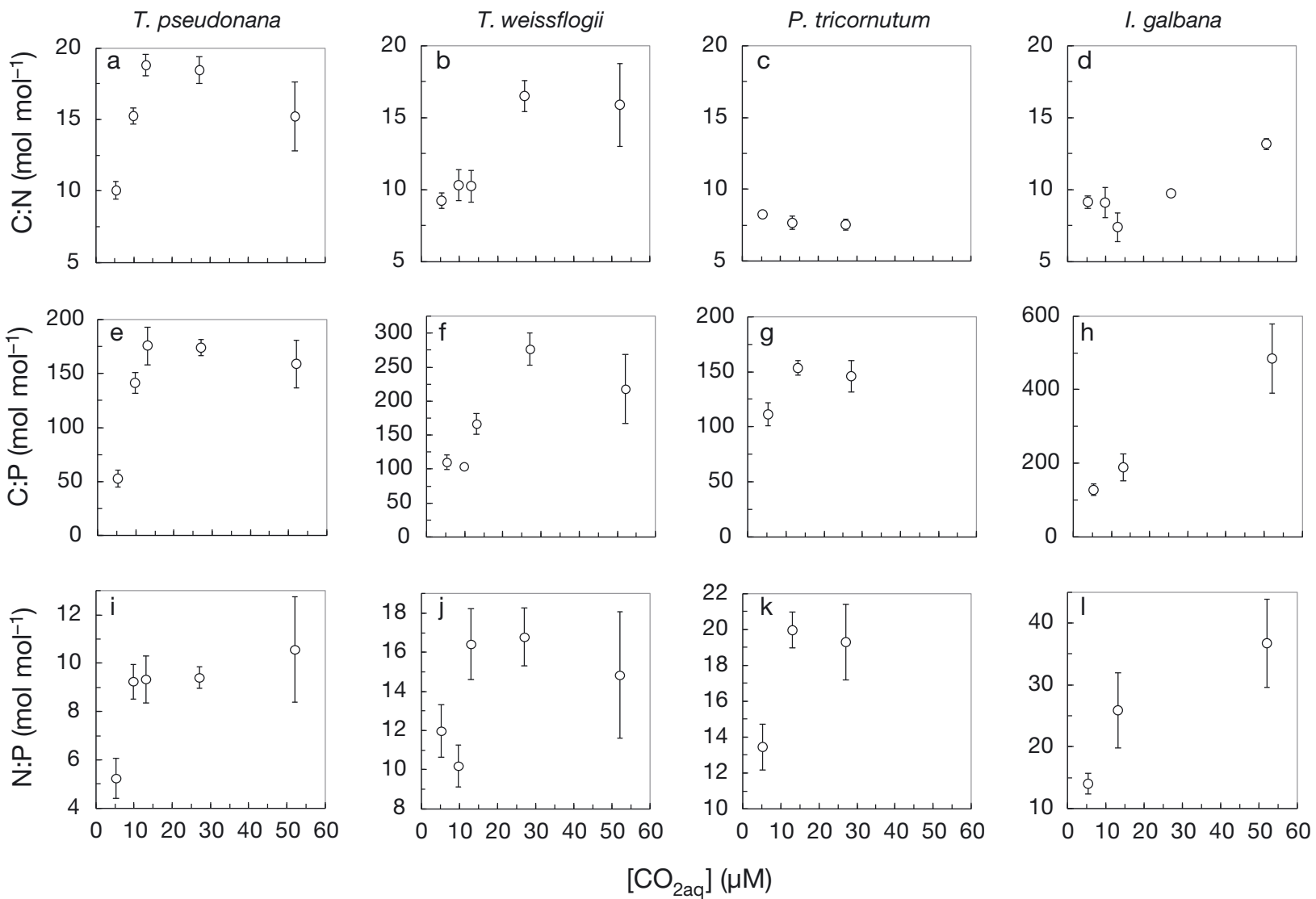

Fig. 1. Element ratios in the marine diatoms (a,e,i) Thalassiosira pseudonana, $(\mathrm{b}, \mathrm{f}, \mathrm{j})$ T. weissflogii, and (c,g,k) Phaeodactylum tricornutum, and $(\mathrm{d}, \mathrm{h}, \mathrm{l})$ the prymnesiophyte Isochrysis galbana acclimated to various concentrations of $\mathrm{CO}_{2}$. Values are ratios of mean element quotas \pm propagated standard deviations

tosynthesis did not vary in Phaeodactylum tricornutum and increased over a higher range of $\mathrm{CO}_{2}(50$ to $13 \mu \mathrm{M}$ ) in Isochrysis galbana.

All 4 species of phytoplankton examined showed declines in phosphorus quotas as $\mathrm{CO}_{2}$ increased from 5 to $13 \mu \mathrm{M}$ (Table 3). Over this range of $\mathrm{CO}_{2}$ concentrations, phosphorus quotas decreased by 62 and $54 \%$ in Thalassiosira pseudonana and T. weissflogii, respectively, and were significantly inversely correlated with $\mathrm{CO}_{2}\left(\mathrm{R}^{2}=0.917, \mathrm{p}<0.05 ; \mathrm{R}^{2}=0.918, \mathrm{p}<\right.$ 0.05). The phosphorus quota in Phaeodactylum tricornutum decreased by more than $37 \%$ in cells acclimated to $13 \mu \mathrm{M} \mathrm{CO}_{2}$ compared with $5 \mu \mathrm{M} \mathrm{CO}_{2}$ and were also inversely correlated with $\mathrm{CO}_{2}\left(\mathrm{R}^{2}=0.997\right.$, $\mathrm{p}<0.01)$. In Isochrysis galbana, the phosphorus quota decreased by $35 \%$ as the acclimation concentration of $\mathrm{CO}_{2}$ increased from 5 to $13 \mu \mathrm{M}$, but this decline was not significant $\left(R^{2}=0.749, p=0.13\right)$.

Declines in nitrogen and phosphorus quotas in cultures acclimated to increasing concentrations of $\mathrm{CO}_{2}$ generally resulted in higher $\mathrm{C}: \mathrm{N}, \mathrm{C}: \mathrm{P}$, and $\mathrm{N}: \mathrm{P}$ ratios (Fig. 1). In Thalassiosira pseudonana, the C:N ratio was positively correlated with $\mathrm{CO}_{2}$ from 5 to $13 \mu \mathrm{M}$ $\left(\mathrm{R}^{2}=0.993, \mathrm{p}<0.01\right)$. However, as acclimation $\mathrm{CO}_{2}$ increased from 13 to $50 \mu \mathrm{M}$, the $\mathrm{C}: \mathrm{N}$ ratio in $T$. pseudonana declined slightly $\left(\mathrm{R}^{2}=0.902, \mathrm{p}<0.05\right)$. Over the $\mathrm{CO}_{2}$ interval of 5 to $10 \mu \mathrm{M}, 40 \%$ of the increase in the C:N ratio in T. pseudonana was due to a decrease in nitrogen quota, but $100 \%$ of the increase in C:N from 10 to $13 \mu \mathrm{M} \mathrm{CO}_{2}$ was due to a decrease in nitrogen quota since the carbon quota was constant over this interval.

$\mathrm{C}: \mathrm{P}$ ratios in Thalassiosira pseudonana were also correlated with $\mathrm{CO}_{2}$ over the range of 5 to $13 \mu \mathrm{M}$ $\left(\mathrm{R}^{2}=0.945, \mathrm{p}<0.01\right)$, but were constant at higher concentrations of $\mathrm{CO}_{2}\left(\mathrm{R}^{2}=0.325, \mathrm{p}=0.32\right.$; Fig. 1e). Over the $\mathrm{CO}_{2}$ interval of 5 to $10 \mu \mathrm{M} \mathrm{CO}_{2}, 70 \%$ of the increase in C:P was due to a decrease in phosphorus quota, while from 10 to $13 \mu \mathrm{M}, 100 \%$ of the increase in the C:P ratio was due to a decrease in phosphorus quota.

$\mathrm{C}: \mathrm{N}$ and $\mathrm{C}: \mathrm{P}$ ratios increased at higher concentrations of $\mathrm{CO}_{2}$ in Thalassiosira weissflogii than in $T$. pseudonana (Fig. 1b,f,j). Both C:N $\left(\mathrm{R}^{2}=0.847, \mathrm{p}<\right.$ 
$0.05)$ and $\mathrm{C}: \mathrm{P}\left(\mathrm{R}^{2}=0.938, \mathrm{p}<0.01\right)$ ratios in T. weissflogii were positively correlated with $\mathrm{CO}_{2}$ over the range of 5 to $27 \mu \mathrm{M}$, with the largest increases occurring between 13 and $27 \mu \mathrm{M}$. Decreases in nitrogen and phosphorus quotas accounted for nearly $100 \%$ of the increase in C:N and C:P ratios in $T$. weissflogii acclimated to $27 \mu \mathrm{M}$ compared with $5 \mu \mathrm{M} \mathrm{CO}_{2}$ and declines in cellular phosphorus accounted for $65 \%$ of the increase in $\mathrm{N}: \mathrm{P}$ ratios in $T$. weissflogii acclimated to high $(13$ to $50 \mu \mathrm{M})$ compared with low $(5$ to $10 \mu \mathrm{M})$ $\mathrm{CO}_{2}$.

In the pennate diatom Phaeodactylum tricornutum, $\mathrm{C}: \mathrm{N}$ ratios were not correlated with $\mathrm{CO}_{2}\left(\mathrm{R}^{2}=0.45\right.$, $\mathrm{p}=0.21$; Fig. 1c). C:P ratios in P. tricornutum increased from 112 to 154 in cells acclimated to $13 \mu \mathrm{M}$ $\mathrm{CO}_{2}$ compared with $5 \mu \mathrm{M} \mathrm{CO}_{2}$, and a lower phosphorus quota accounted for $100 \%$ of this increase (Fig. 1g).

The C:N ratio in Isochrysis galbana did not vary with $\mathrm{CO}_{2}$ in cells acclimated to 5 to $13 \mu \mathrm{M} \mathrm{CO}_{2}\left(\mathrm{R}^{2}=\right.$ $0.551, \mathrm{p}=0.15)$, but was positively correlated with $\mathrm{CO}_{2}$ over the concentration range of 13 to $50 \mu \mathrm{M}\left(\mathrm{R}^{2}\right.$ $=0.937, \mathrm{p}<0.01$; Fig. 1d). Higher carbon quotas accounted for 50 to $100 \%$ of the increases in C:N. C:P ratios in $I$. galbana were positively correlated with $\mathrm{CO}_{2}$ over the entire range of 5 to $50 \mu \mathrm{M}\left(\mathrm{R}^{2}=0.956\right.$, $\mathrm{p}<0.01$; Fig. 1h), and about half of this increase was due to lower phosphorus quotas at high $\mathrm{CO}_{2}$.

$\mathrm{N}: \mathrm{P}$ ratios in all 4 species increased by factors of 1.4 to 1.9 as the concentration of $\mathrm{CO}_{2}$ increased over the range of 5 to $13 \mu \mathrm{M}$ (Fig. 1i-l). In Thalassiosira weissflogii, $\mathrm{N}: \mathrm{P}$ ratios were significantly higher in cells acclimated to $\mathrm{CO}_{2}$ concentrations at or above $13 \mu \mathrm{M}$ than at 5 to $10 \mu \mathrm{M}(\mathrm{p}<0.05, t$-test; Fig. $1 \mathrm{j})$. In T. pseudonana, T. weissflogii, and Phaeodactylum tricornutum, $100 \%$ of the increases in $\mathrm{N}: \mathrm{P}$ with higher $\mathrm{CO}_{2}$ were due to greater declines in phosphorus than nitrogen quotas, while in Isochrysis galbana, $70 \%$ of the increase in $\mathrm{N}: \mathrm{P}$ as $\mathrm{CO}_{2}$ increased from 5 to $13 \mu \mathrm{M}$ was due to a decrease in phosphorus quota.

\section{DISCUSSION}

The present results show that nitrogen and phosphorus quotas vary with $\mathrm{CO}_{2}$ and are generally higher in non-nutrient-limited phytoplankton acclimated to low $\mathrm{CO}_{2}$ compared with cells acclimated to current atmospheric or higher levels of $\mathrm{CO}_{2}$. Nitrogen in phytoplankton is primarily associated with protein and amino acids, although nucleic acids could account for up to $18 \%$ (Lourenço et al. 1998). Phosphorus is used in assembly (ribosomal RNA), structural support (phospholipid), and storage (polyphosphate) components, but the phosphorus contents of marine phytoplankton are not well constrained by biochemical composition (Laws et al. 1983, Geider \& La Roche 2002). The additional nitrogen needed to support inorganic carbon acquisition in phytoplankton cells with CCMs through the production of membrane-bound inorganic carbon transporters and carbonic anhydrase was estimated to account for less than $1 \%$ of cellular nitrogen (Raven 1991, Raven \& Johnston 1991). Most of the cellular nitrogen increment in the centric diatoms Thalassiosira pseudonana and $T$. weissflogii grown at low $\mathrm{CO}_{2}$ was therefore likely due to increased production of proteins responsible for cellular functions (nutrient and light acquisition, photorespiration) other than inorganic carbon accumulation (Raven \& Johnston 1991, Raven et al. 2012). In contrast, while the affinity for inorganic carbon in the pennate diatom Phaeodactylum tricornutum is regulated by $\mathrm{CO}_{2}$ (Rees 1984, Burkhardt et al. 2001), its demand for nitrogen apparently is not.

Increasing carbon and nitrogen quotas in Isochrysis galbana acclimated to 13 to $50 \mu \mathrm{M} \mathrm{CO}_{2}$ (380 to $1500 \mathrm{ppm}$ ) is consistent with results for another marine prymnesiophyte, Phaeocystis globosa grown at 380 and $750 \mathrm{ppm}$ (13 and $25 \mu \mathrm{M}$ ) $\mathrm{CO}_{2}$ (Wang et al. 2010). Although cellular nitrogen decreased at low $\mathrm{CO}_{2}$ in I. galbana, the associated decline in cellular carbon resulted in nitrogen costs of photosynthesis that increased over a higher range of $\mathrm{CO}_{2}$ concentrations (50 to $13 \mu \mathrm{M}$ ) than in the centric diatoms (13 to $5 \mu \mathrm{M})$. This indicates that the carbon-specific nitrogen demand in I. galbana is more sensitive to declining $\mathrm{CO}_{2}$ than in the centric diatoms. The $\mathrm{CCM}$ of I. galbana may therefore help this species conserve nitrogen as $\mathrm{CO}_{2}$ declines through a lower investment in RubisCO and other proteins associated with carbon fixation (Beardall et al. 1998), perhaps at the expense of a lower maximum growth rate compared with diatoms.

Greater phosphorus demand in phytoplankton acclimated to low $\mathrm{CO}_{2}$ is somewhat surprising and not easily explained physiologically (Raven et al. 2011). Higher phosphorus demand at low $\mathrm{CO}_{2}$ may involve increased production of ribosomal RNA to support higher rates of protein turnover, increased phospholipid production to stabilize membranes, or greater phosphate demand for energy storage and use. For the centric diatoms, phosphorus quota of had its largest decline at a higher $\mathrm{CO}_{2}$ concentration in Thalassiosira weissflogii $(46 \%$ decrease between 10 and $13 \mu \mathrm{M}$ ) than in T. pseudonana (52\% decrease 
between 5 and $10 \mu \mathrm{M}$ ). Since relief from $\mathrm{CO}_{2}$-diffusion limitation will occur at a lower concentration of $\mathrm{CO}_{2}$ for the smaller T. pseudonana than for the larger T. weissflogii (Wolf-Gladrow \& Riebesell 1997), T. pseudonana is able to lower its phosphorus requirement at a lower concentration of $\mathrm{CO}_{2}$ than $T$. weissflogii.

Contrary to the present results and those of Clark (2001), in which the concentration of $\mathrm{CO}_{2}$ was set by varying the concentration of DIC at constant $\mathrm{pH}$, nitrogen quotas decreased and phosphorus quotas were relatively constant as $\mathrm{CO}_{2}$ increased from 2 to $31 \mu \mathrm{M} \mathrm{CO} \mathrm{CO}_{2}$ in closed system batch cultures of the diatom Skeletonema costatum in which the concentration of $\mathrm{CO}_{2}$ was controlled by varying $\mathrm{pH}$ (and alkalinity) at constant DIC (Burkhardt \& Riebesell 1997). An important difference between these experimental set-ups is that in the closed system with variable $\mathrm{pH}$ and alkalinity, the concentration of bicarbonate decreases as $\mathrm{CO}_{2}$ is increased, while in the closed system with varying DIC (Clark 2001) or in a gas-equilibrated open system (the present study), the concentrations of $\mathrm{CO}_{2}$ and bicarbonate vary together. Although bicarbonate transport may be saturated at concentrations of 500 to $1000 \mu \mathrm{M}$ (Rost et al. 2003), variation in external bicarbonate concentration, and

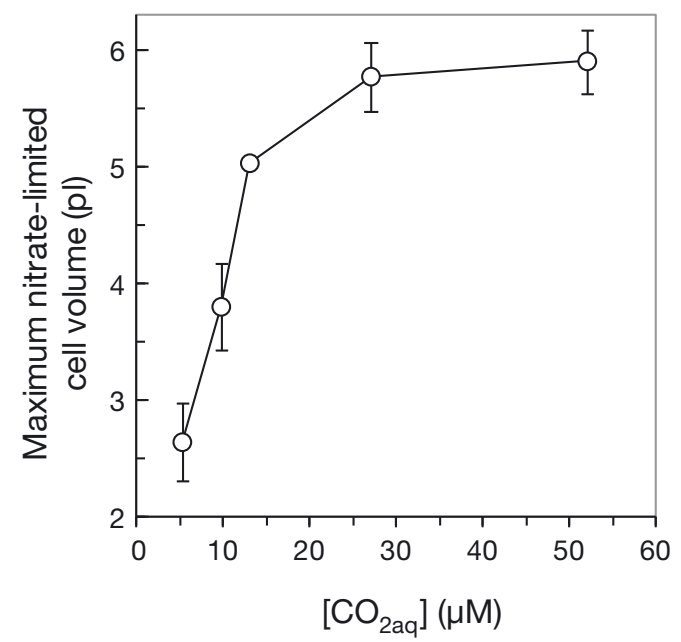

Fig. 2. Thalassiosira pseudonana and T. weissflogii. Carbonnitrogen co-limitation of diatom cell volume. Equivalent spherical cell volumes were calculated from nitratediffusion-limited maximum radii that could support the average $\mathrm{CO}_{2}$-dependent nitrogen quotas measured in the centric diatoms T. pseudonana and T. weissflogii at a growth rate of $1 \mathrm{~d}^{-1}$ and $2 / 3$ of the diffusion-limited nitrate flux with a surface seawater nitrate concentration of $0.5 \mu \mathrm{M}$ (see 'Materials and methods'). Error bars are based on the range of $\mathrm{CO}_{2}$-dependent nitrogen quotas measured in T. pseudonana and T. weissflogii the $\mathrm{pH}$ buffering it provides, could participate in the regulation of the cell's affinity for inorganic carbon and other aspects of its CCM. As a result, the decrease in bicarbonate concentration at high $\mathrm{CO}_{2}$ in $\mathrm{pH}$-controlled cultures may dampen the effects of inorganic carbon supply on cellular carbon and nutrient demands.

Another possible confounding factor in evaluating the effects of $\mathrm{CO}_{2}$ on nutrient quotas is the concentration of nitrogen in culture media and its intracellular storage. Nitrogen quotas follow cell volume in marine diatoms (Marchetti \& Harrison 2007, Timmermans \& van der Wagt 2010). Indeed, cell volumes of Thalassiosira pseudonana and T. weissflogii were up to $50 \%$ higher in cells grown with high nitrate $(300 \mu \mathrm{M})$ than low nitrate $(30 \mu \mathrm{M})$, and in high nitrate cultures of $T$. weissflogii, cell volume increased from 600 to $900 \mathrm{\mu m}^{3}$, but nitrogen quota did not vary $(2.1 \pm$ $0.1 \mathrm{~mol} \mathrm{l}^{-1}$ ) as $\mathrm{CO}_{2}$ increased from 5 to $27 \mu \mathrm{M}$ (data not shown). Thus increased cell size and potentially greater nitrogen storage capacity in cells grown with high nitrogen may mask the effects of $\mathrm{CO}_{2}$ on nitrogen demand.

\section{Carbon-nitrogen co-limitation of diatom cell size}

Greater demand for nitrogen at low $\mathrm{CO}_{2}$ as observed in the 2 centric diatoms in this study could lead to carbon-nitrogen co-limitation of growth and may explain why primary production of some natural phytoplankton communities is apparently limited by $\mathrm{CO}_{2}$ (Hein \& Sand-Jensen 1997, Riebesell et al. 2007). Assuming other nutrients are not limiting, as $\mathrm{CO}_{2}$ increases, lower nitrogen demand could support higher diatom biomass per unit of nitrogen supplied to the surface ocean. Alternatively, $\mathrm{CO}_{2}$ regulation of nitrogen demand could limit the average size of diatoms able to survive in nitrogen-limited surface waters. To explore this possibility, nitrate-diffusionlimited cell volumes of diatoms were estimated based on the $\mathrm{CO}_{2}$-regulated nitrogen quotas measured in Thalassiosira pseudonana and T. weissflogii (Fig. 2). This analysis showed that maximum nitrate-limited diatom cell volume increased from 2.6 to $5.9 \mathrm{pl}$ (equivalent spherical radius of 8.6 to $11.2 \mu \mathrm{m})$ as $\mathrm{CO}_{2}$ increased from 5 to $50 \mu \mathrm{M}$ (150 to $1500 \mathrm{ppm}$ ), with the greatest increase expected between 5 and $13 \mu \mathrm{M}$ (150 to $380 \mathrm{ppm}$ ). According to these trends, higher $\mathrm{CO}_{2}$ would support nearly 2 -fold larger centric diatoms as $\mathrm{CO}_{2}$ increases from 5 to $13 \mu \mathrm{M}$ (150 to $380 \mathrm{ppm}$ ), but only $15 \%$ larger cells from 13 to $27 \mu \mathrm{M}$ (380 to $770 \mathrm{ppm}$ ) $\mathrm{CO}_{2}$. Thus, relatively large in- 
creases in nitrogen-limited diatom cell size could have been supported as the concentration of atmospheric $\mathrm{CO}_{2}$ increased from glacial (180 ppm) to interglacial $(280 \mathrm{ppm})$ values and from interglacial to current post-industrial $(380 \mathrm{ppm})$ values, but a much smaller increase in diatom cell size could be supported by $\mathrm{CO}_{2}$ increases from 380 to $750 \mathrm{ppm}$, as might occur over the next century (IPCC 2007). The effects of carbon-nitrogen co-limitation on diatom cell size may also have played a role in the macroevolution of diatoms during the period of declining atmospheric $\mathrm{CO}_{2}$ from the early to late Cenozoic when there was a marked decline in the size of fossil diatoms (Finkel et al. 2005). The constraint of greater nitrogen demand at low atmospheric $\mathrm{CO}_{2}$ beginning in the early Miocene (24 Ma) to the present (Pagani et al. 2009) may have contributed to the selective pressures favoring smaller diatom cell size (in addition to that caused by low $\mathrm{CO}_{2}$ itself).

Unlike the centric diatoms, the pennate diatoms Phaeodactylum tricornutum (this study) and Pseudonitzschia multiseries (Sun et al. 2011) showed little and no response of nitrogen quotas to $\mathrm{CO}_{2}$, respectively. If these species are representative of other pennates, cell size of this subclass of diatoms would not be expected to vary with $\mathrm{CO}_{2}$, and higher $\mathrm{CO}_{2}$ should favor centric over pennate diatoms as was observed during incubations of Ross Sea phytoplankton (Tortell et al. 2008b, Feng et al. 2010).

\section{$\mathrm{CO}_{2}$ regulation of element ratios in marine phytoplankton}

A rise in $\mathrm{C}: \mathrm{N}$ ratios with increasing $\mathrm{CO}_{2}$, such as that found here in 2 centric diatoms and Isochrysis glabana, was observed previously in marine and freshwater phytoplankton (Clark et al. 1999, Tortell et al. 2000, Clark 2001, Urabe \& Waki 2009, Montechiaro \& Giordano 2010). The lack of an effect of $\mathrm{CO}_{2}$ on C:N in Phaeodactylum tricornutum is consistent with previous studies of pennate diatoms which showed little to no effect of $\mathrm{CO}_{2}$ on $\mathrm{C}: \mathrm{N}$ ratios (Burkhardt et al. 1999, Sun et al. 2011).

Consistent with the present results, C:P and N:P ratios were found to increase with higher $\mathrm{CO}_{2}$ in marine and freshwater diatoms (Burkhardt et al. 1999, Urabe \& Waki 2009, King et al. 2011). Interestingly, there was no effect of $\mathrm{CO}_{2}$ on $\mathrm{C}: \mathrm{P}$ or $\mathrm{N}$ :P ratios in vitamin $\mathrm{B}_{12}$-limited Attheya sp. acclimated to 208, 380 , or $680 \mathrm{ppm}(12,22,39 \mu \mathrm{M}) \mathrm{CO}_{2}$ (King et al. 2011) or in phosphorus-limited Skeletonema costatum acclimated to 4.5 or $21 \mu \mathrm{M} \mathrm{CO}_{2}$ (Gervais \& Riebesell
2001). Nutrient limitation therefore appears to dampen $\mathrm{CO}_{2}$-driven changes in $\mathrm{C}: \mathrm{P}$ and $\mathrm{N}$ :P ratios in centric diatoms, perhaps by lowering the need for a $\mathrm{CCM}$ at low growth rate, although it is not clear whether the reported effects were due to a lack of variation in individual element quotas or to tightly coupled variation among these elements with varying $\mathrm{CO}_{2}$.

The effects of $\mathrm{CO}_{2}$ on element ratios appear to vary widely among marine prymnesiophytes. While the present results show that increasing $\mathrm{CO}_{2}$ leads to higher $\mathrm{C}: \mathrm{N}, \mathrm{C}: \mathrm{P}$, and $\mathrm{N}: \mathrm{P}$ ratios in Isochrysis galbana, relatively minor increases in $\mathrm{C}: \mathrm{N}$ ratios were observed in Phaeocystis globosa or the coccolithophore Emiliania huxleyi grown with elevated $\mathrm{CO}_{2}$ (Engel et al. 2005, Wang et al. 2010). However, increases in C:P and N:P ratios in cultures of $E$. huxleyi acclimated to $750 \mathrm{ppm}(24 \mu \mathrm{M})$ compared to $375 \mathrm{ppm}(12 \mu \mathrm{M}) \mathrm{CO}_{2}$ (Feng et al. 2008) are similar to those observed here in I. galbana. Element ratios did not vary with $\mathrm{CO}_{2}$ in E. huxleyi cultures in which growth was reduced by light limitation (Feng et al. 2008).

Much of the observed $\mathrm{CO}_{2}$-driven changes in $\mathrm{C}: \mathrm{N}$ and C:P ratios (20 to $100 \%$ ) in the species examined here was due to variation in nitrogen and phosphorus quotas rather than changes in cell carbon. Indeed, cellular phosphorus varied with $\mathrm{CO}_{2}$ to a greater extent than nitrogen, accounting for 50 to $100 \%$ of observed changes in C:P ratios and 70 to $100 \%$ of observed changes in N:P ratios. How the cellular use or storage of phosphorus in marine phytoplankton varies with $\mathrm{CO}_{2}$ is currently unknown.

Element ratios in marine phytoplankton regulate the nutrient composition of the deep sea (Arrigo 2005, Lenton \& Klausmeier 2007) and as such are critical to ocean biogeochemistry and its response to global change (Riebesell et al. 2007). These ratios vary with growth conditions including nutrient supply (Laws et al. 1983), temperature (Berges et al. 2002), and light (Finkel et al. 2006), and the present results add to a growing body of evidence that major element ratios in phytoplankton also vary with $\mathrm{CO}_{2}$. In marine diatoms, present and prior results indicate that $\mathrm{C}: \mathrm{N}$ ratios increase as $\mathrm{pCO}_{2}$ increases from 150 to $380 \mathrm{ppm}$, but that these ratios are relatively constant at higher $\mathrm{pCO}_{2} . \mathrm{CO}_{2}$-modulated nitrogen demand in diatoms, and perhaps other classes of phytoplankton (Engel et al. 2005, Barcelos e Ramos et al. 2007, Hutchins et al. 2007, Levitan et al. 2007, Feng et al. 2008), could therefore provide a negative feedback against changing $\mathrm{CO}_{2}$ over the $\mathrm{pCO}_{2}$ range of 150 to $380 \mathrm{ppm}$ by supporting larger cells or higher biomass as $\mathrm{CO}_{2}$ increases and vice versa. However, 
since $\mathrm{C}: \mathrm{N}$ ratios of most marine phytoplankton do not appear to increase above a $\mathrm{pCO}_{2}$ of $380 \mathrm{ppm}$, it is less clear that this phenomenon could provide a carbon sink as atmospheric $\mathrm{CO}_{2}$ rises above 380 ppm over the next 50 to $100 \mathrm{yr}$ (IPCC 2007). In mixed diatomprymnesiophyte mesocosms initiated with 2 and 3 times current atmospheric concentrations of $\mathrm{CO}_{2}$, higher DIC:nitrate drawdown ratios resulted in additional production of extracellular carbon, but no change in particulate $\mathrm{C}: \mathrm{N}$ compared with mesocosms initiated at $350 \mathrm{ppm} \mathrm{CO}_{2}$ (Riebesell et al. 2007). If this result is representative of natural phytoplankton communities, increased carbon fixation at elevated $\mathrm{CO}_{2}$ could enhance the oceanic biological carbon pump, but the effectiveness of extracellular dissolved and particulate organic carbon as a sink for atmospheric $\mathrm{CO}_{2}$ requires further evaluation.

$\mathrm{CO}_{2}$-driven variation in the element contents and ratios of marine phytoplankton reflect the biochemical resource demands that potentially limit photosynthetic carbon fixation and growth at present and lower concentrations of $\mathrm{CO}_{2}$ in the surface ocean. Understanding how the demands for nitrogen, phosphorus, and other nutrients in marine phytoplankton respond to $\mathrm{CO}_{2}$, and how these responses vary with the degree of nutrient or light limitation of growth, is critical to our understanding of the ecological dynamics of marine phytoplankton communities and biogeochemical cycles of nutrient elements in the sea.

Acknowledgements. I acknowledge the assistance of $\mathrm{M}$. Hobor, R. Hossain, and N. Wright in maintaining phytoplankton cultures, and I thank C. Fuller for help with carbon and nitrogen analyses. This project was supported by a grant (OCE 0526365) from the US National Science Foundation's Biological Oceanography program and a Hatch grant through the New Jersey Agricultural Experiment Station.

\section{LITERATURE CITED}

Arrigo KR (2005) Marine microorganisms and global nutrient cycles. Nature 437:349-355

Arrigo KR, Dunbar RB, Lizotte MP, Robinson DH (2002) Taxon-specific differences in C/P and N/P drawdown for phytoplankton in the Ross Sea, Antarctica. Geophys Res Lett 29:1938 doi: 10.1029/200GLO15277

Barcelos e Ramos J, Biswas H, Schulz KG, LaRoche J, Riebesell U (2007) Effect of rising atmospheric carbon dioxide on the marine nitrogen fixer Trichodesmium. Global Biogeochem Cycles 21:GB2028

Beardall J, Giordano M (2002) Ecological implications of microalgal and cyanobacterial $\mathrm{CO}_{2}$ concentrating mechanisms, and their regulation. Funct Plant Biol 29:335-347

Beardall J, Johnston A, Raven J (1998) Environmental regulation of $\mathrm{CO}_{2}$-concentrating mechanisms in microalgae. Can J Bot 76:1010-1017
Berges JA, Varela DE, Harrison PJ (2002) Effects of temperature on growth rate, cell composition and nitrogen metabolism in the marine diatom Thalassiosira pseudonana (Bacillariophyceae). Mar Ecol Prog Ser 225: 139-146

Burkhardt S, Riebesell U (1997) $\mathrm{CO}_{2}$ availability affects elemental composition ( $\mathrm{C}: \mathrm{N}: \mathrm{P})$ of the marine diatom Skeletonema costatum. Mar Ecol Prog Ser 155:67-76

Burkhardt S, Zondervan I, Riebesell U (1999) Effect of $\mathrm{CO}_{2}$ concentration on $\mathrm{C}: \mathrm{N}: \mathrm{P}$ ratio in marine phytoplankton: a species comparison. Limnol Oceanogr 44:683-690

Burkhardt S, Amoroso G, Riebesell U, Sültemeyer D (2001) $\mathrm{CO}_{2}$ and $\mathrm{HCO}_{3}{ }^{-}$uptake in marine diatoms acclimated to different $\mathrm{CO}_{2}$ concentrations. Limnol Oceanogr 46: 1378-1391

Cassar N, Laws EA, Bidigare RR, Popp BN (2004) Bicarbonate uptake by Southern Ocean phytoplankton. Global Biogeochem Cycles 18:GB2003

Clark DR (2001) Growth rate relationships to physiological indices of nutrient status in marine diatoms. J Phycol 37: 249-256

Clark DR, Merrett MJ, Flynn KJ (1999) Utilization of dissolved inorganic carbon (DIC) and the response of the marine flagellate Isochrysis galbana to carbon or nitrogen stress. New Phytol 144:463-470

Clesceri LS, Greenberg AE, Eaton AD (1998) Standard methods for the examination of water and wastewater. American Public Health Association, Washington, DC

Codispoti LA, Friederich GE, Iverson RL, Hood DW (1982) Temporal changes in the inorganic carbon system of the south-eastern Bering Sea during spring 1980. Nature 296:242-245

> Dason JS, Huertas IE, Colman B (2004) Source of inorganic carbon for photosynthesis in two marine dinoflagellates. J Phycol 40:285-292

Engel A, Zondervan I, Aerts K, Beaufort L and others (2005) Testing the direct effect of $\mathrm{CO}_{2}$ concentration on a bloom of the coccolithophorid Emiliania huxleyi in mesocosm experiments. Limnol Oceanogr 50:493-507

Feely RA, Boutin J, Cosca CE, Dandonneau Y and others (2002) Seasonal and interannual variability of $\mathrm{CO}_{2}$ in the equatorial Pacific. Deep-Sea Res II 49:2443-2469

> Feng Y, Warner ME, Zhang Y, Sun J, Fu FX, Rose JM, Hutchins DA (2008) Interactive effects of increased $\mathrm{pCO}_{2}$, temperature and irradiance on the marine coccolithophore Emiliania huxleyi (Prymnesiophyceae). Eur J Phycol 43:87-98

> Feng Y, Hare CE, Rose JM, Handy SM and others (2010) Interactive effects of iron, irradiance and $\mathrm{CO}_{2}$ on Ross Sea phytoplankton. Deep-Sea Res I 57:368-383

- Finkel ZV, Katz ME, Wright JD, Schofield OME, Falkowski PG (2005) Climatically driven macroevolutionary patterns in the size of marine diatoms over the Cenozoic. Proc Natl Acad Sci USA 102:8927-8932

- Finkel ZV, Quigg A, Raven JA, Reinfelder JR, Schofield OE, Falkowski PG (2006) Irradiance and the elemental stoichiometry of marine phytoplankton. Limnol Oceanogr 51:2690-2701

Geider RJ, La Roche J (2002) Redfield revisited: variability of $\mathrm{C}: \mathrm{N}: \mathrm{P}$ in marine microalgae and its biochemical basis. Eur J Phycol 37:1-17

Gervais F, Riebesell U (2001) Effect of phosphorus limitation on elemental composition and stable carbon isotope fractionation in a marine diatom growing under different $\mathrm{CO}_{2}$ concentrations. Limnol Oceanogr 46:497-504 
Giordano M, Beardall J, Raven JA (2005) $\mathrm{CO}_{2}$ concentrating mechanisms in algae: Mechanisms, environmental modulation, and evolution. Annu Rev Plant Biol 56:99-131

Goldman JC, McCarthy JJ, Peavey DG (1979) Growth rate influence on the chemical composition of phytoplankton in oceanic waters. Nature 279:210-215

Hales B, Takahashi T, Bandstra L (2005) Atmospheric $\mathrm{CO}_{2}$ uptake by a coastal upwelling system. Global Biogeochem Cycles 19:GB1009

> Hein M, Sand-Jensen K (1997) $\mathrm{CO}_{2}$ increases oceanic primary production. Nature 388:526-527

> Ho TY, Quigg A, Finkel ZV, Milligan AJ, Wyman K, Falkowski PG, Morel FMM (2003) The elemental composition of some marine phytoplankton. J Phycol 39: 1145-1159

Hopkinson BM, Dupont CL, Allen AE, Morel FMM (2011) Efficiency of the $\mathrm{CO}_{2}$-concentrating mechanism of diatoms. Proc Natl Acad Sci USA 108:3830-3837

Hutchins DA, Fu FX, Zhang Y, Warner ME and others (2007) $\mathrm{CO}_{2}$ control of Trichodesmium $\mathrm{N}_{2}$ fixation, photosynthesis, growth rates, and elemental ratios: implications for past, present, and future ocean biogeochemistry. Limnol Oceanogr 52:1293-1304

Hutchins DA, Mulholland MR, Fu F (2009) Nutrient cycles and marine microbes in a $\mathrm{CO}_{2}$-enriched ocean. Oceanography (Wash DC) 22:128-145

IPCC (Intergovernmental Panel on Climate Change) (2007) Climate Change 2007: synthesis report. Contributions of Working Groups I, II and III to the Fourth Assessment Report of the Intergovernmental Panel on Climate Change. IPCC, Geneva

Karl DM, Tilbrook B, Tien G (1991) Seasonal coupling of organic matter production and particle flux in the western Bransfield Strait, Antartica. Deep-Sea Res A 38:1097-1126

King AL, Sanudo-Wilhelmy SA, Leblanc K, Hutchins DA, Fu FX (2011) $C_{2}$ and vitamin $B_{12}$ interactions determine bioactive trace metal requirements of a subarctic Pacific diatom. ISME J 5:1388-1396

Laws EA, Redalje DG, Karl DM, Chalup M (1983) A theoretical and experimental examination of the predictions of two recent models of phytoplankton growth. J Theor Biol 105:469-491

Lenton TM, Klausmeier CA (2007) Biotic stoichiometric controls on the deep ocean N:P ratio. Biogeosciences 4 : 353-367

> Leonardos N, Geider RJ (2004) Effects of nitrate: phosphate supply ratio and irradiance on the C: N: P stoichiometry of Chaetoceros muelleri. Eur J Phycol 39:173-180

Levitan O, Rosenberg G, Setlik I, Setlikova E and others (2007) Elevated $\mathrm{CO}_{2}$ enhances nitrogen fixation and growth in the marine cyanobacterium Trichodesmium. Glob Change Biol 13:531-538

Lewis E, Wallace DWR (1998) Program developed for $\mathrm{CO}_{2}$ system calculations. ORNL/CDIAC-105. Carbon Dioxide Information Analysis Center, Oak Ridge National Laboratory, US Department of Energy, Oak Ridge, TN

Lourenço SO, Barbarino E, Marquez UML, Aidar E (1998) Distribution of intracellular nitrogen in marine microalgae: basis for the calculation of specific nitrogen-toprotein conversion factors. J Phycol 34:798-811

Lüthi D, Le Floch M, Bereiter B, Blunier T and others (2008) High-resolution carbon dioxide concentration record $650,000-800,000$ years before present. Nature 453: 379-382

Marchetti A, Harrison PJ (2007) Coupled changes in the cell morphology and elemental $(\mathrm{C}, \mathrm{N}$, and $\mathrm{Si}$ ) composition of the pennate diatom Pseudo-nitzschia due to iron deficiency. Limnol Oceanogr 52:2270-2284

McGinn PJ, Morel FMM (2008) Expression and inhibition of the carboxylating and decarboxylating enzymes in the photosynthetic C-4 pathway of marine diatoms. Plant Physiol 146:300-309

> Montechiaro F, Giordano M (2010) Compositional homeostasis of the dinoflagellate Protoceratium reticulatum grown at three different $\mathrm{pCO}_{2}$. J Plant Physiol 167:110-113

Moore CM, Hickman AE, Poulton AJ, Seeyave S, Lucas MI (2007) Iron-light interactions during the CROZet natural iron bloom and EXport experiment (CROZEX): II-Taxonomic responses and elemental stoichiometry. Deep-Sea Res II 54:2066-2084

Morel FMM, Reinfelder JR, Roberts SB, Chamberlain CP, Lee JG, Yee D (1994) Zinc and carbon co-limitation of marine phytoplankton. Nature 369:740-742

Murata A, Kumamoto Y, Saito C, Kawakami H, Asanuma I, Kusakabe M, Inoue HY (2002) Impact of a spring phytoplankton bloom on the $\mathrm{CO}_{2}$ system in the mixed layer of the northwestern North Pacific. Deep-Sea Res II 49: 5531-5555

Nakamura Y, Suzuki S, Hiromi J (1995) Growth and grazing of a naked heterotrophic dinoflagellate, Gyrodinium dominans. Aquat Microb Ecol 9:157-164

Pagani M, Caldeira K, Berner R, Beerling DJ (2009) The role of terrestrial plants in limiting atmospheric $\mathrm{CO}_{2}$ decline over the past 24 million years. Nature 460:85-88

Parsons TR, Maita Y, Lalli CM (1984) Manual of chemical and biological methods for seawater analysis. Pergamon Press, Oxford

> Price NM (2005) The elemental stoichiometry and composition of an iron-limited diatom. Limnol Oceanogr 50: 1159-1171

Price N, Harrison G, Hering J, Hudson R, Nirel P, Palenik B, Morel F (1988/89) Preparation and chemistry of the artificial algal culture medium Aquil. Biol Oceanogr 6: 443-461

Quigg A, Finkel ZV, Irwin AJ, Rosenthal Y and others (2003) The evolutionary inheritance of elemental stoichiometry in marine phytoplankton. Nature 425:291-294

- Raven JA (1991) Physiology of inorganic C acquisition and implications for resource use efficiency by marine phytoplankton: relation to increased $\mathrm{CO}_{2}$ and temperature. Plant Cell Environ 14:779-794

Raven JA, Johnston AM (1991) Mechanisms of inorganic carbon acquisition in marine phytoplankton and their implications for the use of other resources. Limnol Oceanogr 36:1701-1714

> Raven JA, Giordano M, Beardall J, Maberly SC (2011) Algal and aquatic plant carbon concentrating mechanisms in relation to environmental change. Photosynth Res 109: 281-296

> Raven JA, Giordano M, Beardall J, Maberly SC (2012) Algal evolution in relation to atmospheric $\mathrm{CO}_{2}$ : carboxylases, carbon-concentrating mechanisms and carbon oxidation cycles. Philos Trans R Soc Lond B Biol Sci 367:493-507

Rees TAV (1984) Sodium dependent photosynthetic oxygen evolution in a marine diatom. J Exp Bot 35:332-337

Reinfelder JR (2011) Carbon concentrating mechanisms in eukaryotic marine phytoplankton. Annu Rev Mar Sci 3: 291-315

> Reinfelder JR, Kraepiel AML, Morel FMM (2000) Unicellular C4 photosynthesis in a marine diatom. Nature 407: 
996-999

Reinfelder JR, Milligan AJ, Morel FMM (2004) The role of the $\mathrm{C} 4$ pathway in carbon accumulation and fixation in a marine diatom. Plant Physiol 135:2106-2111

Riebesell U, Schulz KG, Bellerby RGJ, Botros M and others (2007) Enhanced biological carbon consumption in a high $\mathrm{CO}_{2}$ ocean. Nature 450:545-548

Roberts K, Granum E, Leegood RC, Raven JA (2007) C-3 and C-4 pathways of photosynthetic carbon assimilation in marine diatoms are under genetic, not environmental, control. Plant Physiol 145:230-235

Rost B, Riebesell U, Burkhardt S, Sultemeyer D (2003) Carbon acquisition of bloom-forming marine phytoplankton. Limnol Oceanogr 48:55-67

Rost B, Zondervan I, Wolf-Gladrow D (2008) Sensitivity of phytoplankton to future changes in ocean carbonate chemistry: current knowledge, contradictions and research directions. Mar Ecol Prog Ser 373:227-237

Roy RN, Roy LN, Vogel KM, Porter-Moore C and others (1993) The dissociation constants of carbonic acid in seawater at salinities 5 to 45 and temperatures 0 to $45^{\circ} \mathrm{C}$. Mar Chem 44:249-267

Shi D, Xu Y, Morel FMM (2009) Effects of the $\mathrm{pH} / \mathrm{pCO}_{2}$ control method on medium chemistry and phytoplankton growth. Biogeosciences 6:1199-1207

Sun J, Hutchins DA, Feng Y, Seubert EL, Caron DA, Fu FX (2011) Effects of changing $\mathrm{pCO}_{2}$ and phosphate availability on domoic acid production and physiology of the marine harmful bloom diatom Pseudo-nitzschia multiseries. Limnol Oceanogr 56:829-840

Timmermans KR, van der Wagt B (2010) Variability in cell size, nutrient depletion, and growth rates of the Southern Ocean diatom Fragilariopsis kerguelensis (Bacillariophyceae) after prolonged iron limitation. J Phycol 46: 497-506

Tortell PD, Reinfelder JR, Morel FMM (1997) Active uptake

Editorial responsibility: Graham Savidge,

Portaferry, UK of bicarbonate by diatoms. Nature 390:243-244

> Tortell PD, Rau GH, Morel FMM (2000) Inorganic carbon acquisition in coastal Pacific phytoplankton communities. Limnol Oceanogr 45:1485-1500

Tortell PD, DiTullio GR, Sigman DM, Morel FMM (2002) $\mathrm{CO}_{2}$ effects on taxonomic composition and nutrient utilization in an Equatorial Pacific phytoplankton assemblage. Mar Ecol Prog Ser 236:37-43

Tortell PD, Payne C, Gueguen C, Strzepek RF, Boyd PW, Rost B (2008a) Inorganic carbon uptake by Southern Ocean phytoplankton. Limnol Oceanogr 53:1266-1278

> Tortell PD, Payne CD, Li YY, Trimborn S and others (2008b) $\mathrm{CO}_{2}$ sensitivity of Southern Ocean phytoplankton. Geophys Res Lett 35:L04605 doi: 10.1029/2007GL032583

> Trimborn S, Wolf-Gladrow D, Richter KU, Rost B (2009) The effect of $\mathrm{pCO}_{2}$ on carbon acquisition and intracellular assimilation in four marine diatoms. J Exp Mar Biol Ecol 376:26-36

Urabe J, Waki N (2009) Mitigation of adverse effects of rising $\mathrm{CO}_{2}$ on a planktonic herbivore by mixed algal diets. Glob Change Biol 15:523-531

- Varela DE, Willers V, Crawford DW (2011) Effect of zinc availability on growth, morphology, and nutrient incorporation in a coastal and an oceanic diatom. J Phycol 47: 302-312

Wang Y, Smith WO Jr, Wang X, Li S (2010) Subtle biological responses to increased $\mathrm{CO}_{2}$ concentrations by Phaeocystis globosa Scherffel, a harmful algal bloom species. Geophys Res Lett 37:L09604 doi: 10.1029/2010GL042666

> Wolf-Gladrow D, Riebesell U (1997) Diffusion and reactions in the vicinity of plankton: a refined model for inorganic carbon transport. Mar Chem 59:17-34

> Yeh HS, Wills GB (1970) Diffusion coefficient of sodium nitrate in aqueous solution at 25.deg. as a function of concentration from 0.1 to $1.0 \mathrm{M}$. J Chem Eng Data 15: $187-189$

Submitted: January 25, 2012; Accepted: June 22, 2012

Proofs received from author(s): September 29, 2012 